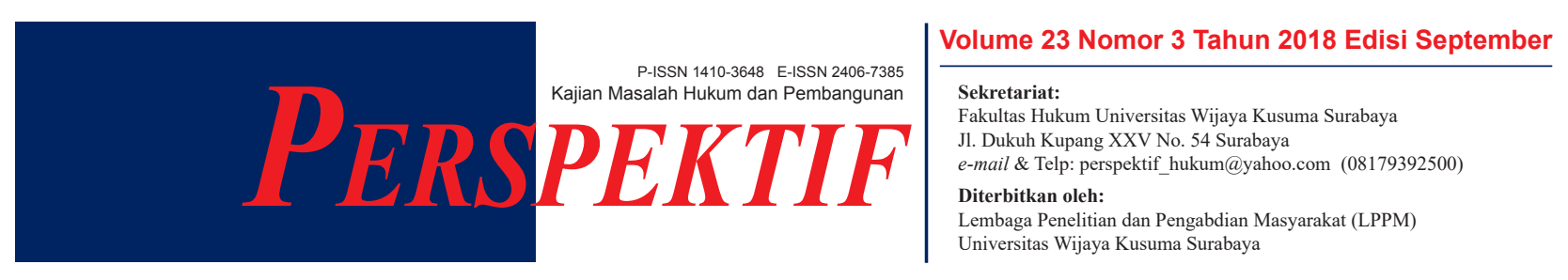

\title{
KEDUDUKAN HUKUM \\ PEMEGANG HAK MILIK ATAS TANAH PERTANIAN YANG MELEBIHI BATAS MAKSIMUM
}

\author{
Rani Rizkiyanti \\ Magister Kenotariatan, Universitas Airlangga \\ e-mail:vespalova07@gmail.com
}

\begin{abstract}
ABSTRAK
UUPA mengenal pembatasan kepemilikan tanah, hal ini diatur dalam Pasal 7 dan Pasal 17. Disebutkan lebih lanjut dalam Pasal 17 UUPA bahwa pembatasan kepemilikan tanah itu berlaku untuk satu keluarga maupun badan hukum. Penetapan batas maksimum kepemilikan tanah ini diatur dalam Undang-undang Nomor 56 Prp Tahun 1960 tentang penetapan luas tanah pertanian. Manakala ada pemilik tanah pertanian yang melebihi batas maksimum, maka kepemilikan hak atas tanah tersebut sudah seharusnya terkena ketentuan redistribusi tanah dan mendapatkan ganti rugi bagi bekas pemilik tanah pertanian yang melebihi batas maksimum. Pasal 7 UUPA menyebutkan bahwa untuk tidak merugikan kepentingan umum, maka pemilikan dan penguasaan tanah yang melampaui batas tidak diperkenankan. Menjadi permaslahan bagaimana kedudukan hukum pemilik tanah yang melebihi batas tersebut. Hasil yang didapatkan dari penulisan ini adalah ada beberapa faktor dan syarat-syarat yang harus dipenuhi oleh penerima redistribusi dan bekas pemilik tanah pertanian. Tahapan mekanisme redistribusi tanah-tanah pertanian yang melebihi batas maksimum itu diawali dari kegiatan pendaftaran dan penelitian, tindakan penetapan bagian tanah untuk bekas pemilik, bahan-bahan keterangan untuk pemberian ganti rugi, pendaftaran para penggarap, pemberian ijin untuk mengerjakan tanah-tanah pertanian yang melebihi batas maksimum, dan yang terakhir adalah redistribusi atau pembagian tanah kepada para petani yang telah memenuhi syarat-syarat yang telah ditentukan oleh Peraturan Perundang-undangan.
\end{abstract}

Kata Kunci: hak milik atas tanah pertanian; landreform; redistribusi; ganti rugi

\section{ABSTRACT}

The UUPA recognizes land ownership restrictions, this is regulated in Article 7 and Article 17, which in Article 7 contains that not to harm the public interest, ownership and control of land that exceeds that limit is not permitted. Further mentioned in article 17 of the UUPA that the limitation of land ownership applies to one family and legal entity. Determination of the maximum limit of land ownership is regulated in Law Number 56 Prp of 1960 concerning the determination of the extent of agricultural land. When there is an agricultural land owner who exceeds the maximum limit, the ownership of the land rights should be subject to the provisions of land redistribution and obtain compensation for former owners of agricultural land that exceeds the maximum limit. Article 7 of the UUPA states that to not harm the public interest, ownership and control of land that exceeds the limit is not permitted. It becomes a problem of how the legal position of landowners exceeds this limit. The results obtained from this paper are that there are several factors and conditions that must be met by recipients of redistribution and former owners of agricultural land. The stages of the mechanism of redistribution of agricultural lands that exceed the maximum limit are initiated from registration and research activities, actions to determine land parts for former owners, information materials for compensation, registration of cultivators, granting permission to work on agricultural lands that exceed the maximum limit, and the last is the redistribution or division of land to farmers who have fulfilled the conditions specified by the legislation.

Keywords: Property right over agricultural land; landreform; redistribution; compensation 


\section{PENDAHULUAN}

Negara Kesatuan Republik Indonesia yang berdasarkan UUD 1945 adalah negara hukum yang memberikan jaminan dan perlindungan atas hak-hak warga negara, antara lain hak warga negara untuk mendapatkan, mempunyai, dan menikmati hak milik. ${ }^{1}$ Hak milik sangat penting bagi manusia untuk dapat melaksanakan hidupnya di dunia. Semakin tinggi nilai hak milik atas suatu benda, semakin tinggi pula penghargaan yang diberikan terhadap benda tersebut.

Tanah adalah salah satunya milik yang sangat berharga bagi umat manusia, demikian pula untuk Bangsa Indonesia. ${ }^{2}$ Tanah memiliki hubungan yang sangat erat dengan manusia. Tanah merupakan tempat untuk hidup dan sebagai sumber kehidupan. Manusia hidup dan berkembang biak serta melakukan aktivitas di atas tanah, sehingga setiap manusia berhubungan dengan tanah.

Kebutuhan akan tanah tidak hanya di sektor pertanian dan pemukiman saja, namun kebutuhan akan tanah juga diperlukan untuk mendirikan komplek peristirahatan, infrastruktur perkantoran, pabrik dan yang lainnya di mana hal ini jelas sangat membutuhkan tanah yang luas. Kebutuhan akan tanah meningkat seiring dengan perkembangan pembangunan baik di sektor ekonomi, pendidikan, pemerintah, agama dan lain-lain. Semakin lama semakin banyak orang yang memerlukan dan menggunakan tanah maka hak-hak kepemilikan tanah di negeri ini juga semakin bertambah kompleks dan beragam.

Kepemilikan tanah dibagi atas nama perorangan atau pun kelompok, baik swasta maupun pemerintah. Dalam prakteknya ada pihak yang memiliki begitu banyak tanah bahkan sampai memiliki tanah secara ganda atau memiliki tanah yang melewati batas maksimum, namun ada juga pihak yang tidak memiliki tanah sama sekali. Bahkan tidak sedikit petani di negeri ini yang tidak mempunyai tanah padahal pekerjaannya adalah bertani atau bercocok tanam.

Tanah wajib untuk didaftarkan, tujuan dari didaftarkannya tanah tersebut adalah untuk memberikan kepastian hukum dan perlindungan

\footnotetext{
${ }^{1}$ Adrian Sutedi. (2008). Peralihan Hak Atas Tanah dan Pendaftarannya. Jakarta: Sinar Grafika, h. 1.

2 ibid., h. 7.
}

hukum kepada pemegang hak atas tanah dengan alat bukti yang dihasilkan pada akhir proses pendaftaran berupa buku tanah atau sertipikat tanah. Sertipikat tanah hanya sebagai tanda bukti hak yang kuat dan bukan merupakan bukti yang mutlak.

Pendaftaran tanah adalah rangkaian kegiatan yang dilakukan oleh pemerintah secara terus menerus, berkesinambungan dan teratur, meliputi pengumpulan, pengolahan, pembukuan, dan penyajian serta pemeliharaan data fisik dan data yuridis, dalam bentuk peta dan daftar, mengenai bidang-bidang tanah dan satuan-satuan rumah susun, termasuk pemberian surat tanda bukti haknya bagi bidang-bidang tanah yang sudah ada haknya dan hak milik atas satuan rumah susun serta hak-hak tertentu yang membebaninya.

Pendaftaran tanah yang bertujuan memberikan jaminan kepastian hukum dikenal dengan sebutan Rechts Cadaster/Legal Cadaster. Jaminan kepastian hukum yang hendak diwujudkan dalam pendaftaran tanah ini, meliputi kepastian status hak yang didaftar, kepastian subjek hak, dan kepastian objek hak. Kebalikan dari pendaftaran tanah yang bertujuan Rechts Cadaster, adalah Fiscal Cadaster, yaitu pendaftaran tanah yang bertujuan untuk menetapkan siapa yang wajib membayar pajak atas tanah. Pendaftaran tanah ini menghasilkan surat tanda bukti pembayaran pajak atas tanah, yang sekarang dikenal dengan sebutan surat pemberitahuan pajak terutang pajak bumi dan bangunan. ${ }^{3}$

Pembatasan luas maksimal pemilikan tanah telah diatur di dalam Undang-Undang dan Peraturan Pemerintah. Pembatasan luas maksimal pemilikan tanah merupakan program pertama dari Land Reform. Dasar hukum dari land reform adalah Undang-Undang Pokok Agraria Nomor 5 Tahun 1960 (selanjutnya disebut UUPA) Pasal 7, 10, 17, dan 24, Undang-Undang Nomor 56 Prp tahun 1960 tentang Penetapan Luas Tanah Pertanian, dan Peraturan Pemerintah Nomor 224 Tahun 1961 tentang Pelaksanaan Pembagian Tanah dan Pemberian Ganti Rugi. ${ }^{4}$

${ }^{3}$ Urip Santoso. (2014). Pendaftaran dan Peralihan Hak Atas Tanah. Cet. IV. Jakarta: Kencana Prenadamedia Group, h. 2. (Selanjutnya disebut Urip Santoso I)

${ }^{4}$ Aslan Noor. (2006). Konsep Hak Milik Atas Tanah Bagi Bangsa Indonesia Ditinjau Dari HAM. Cet. I. Jakarta: Mandar Maju, h. 269. 
Fungsi sosial di dalam UUPA dimaknai sebagai suatu fungsi yang mendalam, bahwa dalam setiap hak seseorang terkandung hak dari masyarakat. Artinya ialah di atas tanah hak seseorang ada porsi hak orang lain (Pasal 6 UUPA). Semua hak atas tanah mempunyai fungsi sosial. Ini berarti bahwa hak atas tanah apapun yang ada pada seseorang tidaklah dapat dibenarkan bahwa tanahnya akan dipergunakan/tidak dipergunakan semata-semata untuk kepentingan pribadinya atau hal itu menimbulkan kerugian bagi masyarakat.

Hak atas tanah adalah hak yang memberi wewenang kepada pemegang hak untuk menggunakan atau mengambil manfaat dari tanah yang dihakinya. Penggunaan tanah harus disesuaikan dengan keadaan dan sifat dari pada haknya, sehingga bermanfaat baik bagi kesejahteraan dan kebahagiaan yang memilikinnya maupun bermanfaat bagi masyarakat dan negara. Ketentuan itu tidak berarti kepentingan perorangan akan terdesak oleh kepentingan umum. Tanah harus dipelihara dengan baik dan dicegah kerusakannya. Kewajiban ini tidak hanya dibebankan pada pemegang hak yang bersangkutan, tetapi juga setiap orang/badan hukum ataupun instansi yang mempunyai hubungan hukum dengan tanah itu. ${ }^{5}$

Tanah Pertanian di dalam UUPA disebutkan bahwa tanah pertanian harus dikerjakan secara aktif oleh pemiliknya. Untuk melaksanakan ketentuan tersebut, perlu ada ketentuan batas maksimum pemilikan tanah sehingga dapat mencegah tertumpuknya tanah pada golongan tertentu. Pemilikan batas maksimum juga tidak selalu terdeteksi dan hal-hal seperti ini yang membuat program landreform menjadi macet.

Di kota-kota yang mengalami perkembangan pembangunan yang sangat pesat, kebutuhan akan tanah semakin meningkat, pada kenyataanya tanah yang tersedia tidak bertambah luasnya. Harga tanah meningkat sedangkan warga kota golongan ekonomi lemah yang mengalami akibat pertumbuhan penduduk dan urbanisasi tidak mampu lagi untuk memperoleh tanah untuk kepentingan tempat tinggalnya.

Di dalam UUPA pembatasan kepemilikan tanah ini diatur dalam Pasal 7 dan 17, yang mana di dalam Pasal 7 berisi bahwa untuk tidak merugikan kepentingan umum, maka pemilikan dan penguasaan tanah yang melampaui batas tidak diperkenankan.

\footnotetext{
${ }^{5}$ Achmad Chulaimi. (2007). Hukum Agraria. Semarang: Fakultas Hukum Universitas Diponegoro, h. 21.
}

Disebutkan lebih lanjut dalam Pasal 17 UUPA bahwa pembatasan kepemilikan tanah itu berlaku untuk satu keluarga maupun badan hukum. Penetapan batas maksimum kepemilikan tanah ini diatur dalam Undang-Undang Nomor 56 Prp Tahun 1960 tentang Penetapan Luas Tanah Pertanian.

Pemilik tanah pertanian yang melebihi batas maksimum maka kepemilikan hak atas tanah tersebut sudah seharusnya terkena ketentuan redistribusi tanah dan mendapatkan ganti rugi bagi bekas pemilik tanah pertanian yang melebihi batas maksimum. Pasal 7 UUPA menyebutkan bahwa untuk tidak merugikan kepentingan umum, maka pemilikan dan penguasaan tanah yang melampaui batas tidak diperkenankan. ${ }^{6}$

\section{PERUMUSAN MASALAH}

Berdasarkan uraian pada latar belakang di atas, maka dapat dirumuskan beberapa pokok permasalahan sebagai berikut: Bagaimana kedudukan hukum pemilik tanah pertanian yang melebihi batas maksimum, serta mekanisme redistribusi tanah pertanian yang melebihi batas maksimum berdasarkan aturan perundang-undangan.

\section{PEMBAHASAN}

\section{Fungsi Pendaftaran Hak Atas Tanah}

Pendaftaran menurut Harun Al Rashid, berasal dari kata cadastre, yaitu suatu istilah teknis untuk suatu rekaman, menunjukan kepada luas, nilai, dan kepemilikan (atau lain-lain atas hak) terhadap suatu bidang tanah. ${ }^{7}$ Menurut Boedi Harsono pengertian Pendaftaran Tanah adalah suatu rangkaian kegiatan yang dilakukan oleh Negara/Pemerintah secara terus menerus dan teratur, berupa pengumpulan keterangan atau data tertentu mengenai tanah-tanah tertentu yang ada di wilayah-wilayah tertentu, pengolahan, penyimpanan, dan penyajiannya bagi kepentingan rakyat, dalam rangka menjamin kepastian hukum dibidang pertanahan, termasuk penerbitan tanda bukti dan pemeliharaannya. ${ }^{8}$

Berdasarkan pengertian dari Boedi Harsono tersebut, pendaftaran tanah dapat dibedakan menjadi dua, yaitu pendaftaran tanah untuk pertama kali, dan

\footnotetext{
${ }^{6}$ Aslan Noor. op.cit., h. 260.

${ }^{7}$ Harun Al Rashid. (1996). Sekilas Tentang Jual Beli Tanah (Berikut Peraturan-Peraturan). Jakarta: Ghalia Indonesia, h. 82.

${ }^{8}$ Boedi Harsono. (2003). Hukum Agraria Indonesia, Jilid 1 Tanah Nasional. Jakarta: Djambatan, h. 72.
} 
pemeliharaan data pendaftaran tanah. Pendaftaran Tanah dapat dilakukan terhadap obyek tanah yang belum didaftar berdasarkan Peraturan Pemerintah No. 24 Tahun 1997 (selanjutnya disebut PP Pendaftaran Tanah). Sedangkan pemeliharaan data pendaftaran tanah merupakan kegiatan pendaftaran tanah untuk menyesuaikan data fisik dan data yuridis dalam peta pendaftaran, daftar tanah, daftar nama, surat ukur, buku tanah, dan sertipikat karena adanya perubahanperubahan yang terjadi kemudian. Secara umum kegiatan pendaftaran tanah, meliputi: ${ }^{9}$

1. Bidang fisik, yaitu pengukuran, pemetaan dan pembukuan yang menghilangkan peta-peta pendaftaran dan surat ukur;

2. Bidang Yuridis, yaitu pendaftaran hak-hak atas tanah, peralihan hak dan pendaftaran atau pencatatan dari hak-hak lain (baik Hak Atas Tanah maupun jaminman) serta beban-baban lainnya;

3. Penerbitan surat tanda bukti hak (sertipikat).

Secara lebih spesifik, Ali Achmad menjabarkan bahwa pendaftaran tanah meliputi kegiatan sebagai berikut: ${ }^{10}$

1. Berkas permohonan hak diteliti dan diproses oleh Aparatur Pertanahan di Tingkat Kabupaten/ Kotamadya (diadakan pengukuran, pemetaan, dan pemeriksaan tanah setempat, yang dilakukan oleh Seksi Penatagunaan Tanah, Pendaftaran Tanah dan Panitia);

2. Jika semua persyaratan telah lengkap, berkas permohonan Hak Atas Tanah disampaikan kepada Kepala Kantor Wilayah Badan Pertanahan Nasional Propinsi untuk diterbitkan Surat Keputusan;

3. Jika wewenang untuk memberikan Keputusan Pemberian Hak Milik ada pada Kepada Kantor Wilayah Badan Pertanahan Nasional Propinsi, maka berkas permohonan Hak dimaksud diteruskan kepada Kepala Badan Pertanahan Nasional untuk mendapatkan penyelesaiannya;

4. Setelah menerima Surat Keputusan Kepala Badan Pertanahan Nasional atau Kepala Kantor Wilayah Badan Pertanahan Nasional Propinsi sesuai dengan kewenangannya maka pihak Pemohon

\footnotetext{
${ }^{9}$ op.cit.

10 Ali Achmad Chomzah. (2002). Hukum Pertanahan. Jakarta: Prestasi Pustaka, h. 10-11.
}

segera memenuhi kewajiban-kewajiban yang ditetapkan dalam surat keputusan;

5. Membuat Tanda Batas;

6. Memenuhi persyaratan-persyaratan yang ditetapkan terkait Tata Guna Tanah;

7. Semua syarat-syarat dan kewajiban tersebut apabila telah dipenuhi, maka Pemohon/Penerima Hak harus di segera mendaftarkan tanahnya tersebut pada Kantor Pertanahan Kabupaten/ Kotamadya setempat untuk mendapatkan sertipikat, dengan menyerahkan bukti:

a. Surat keputusan Pemberian Hak Milik;

b. Bukti Pembayaran uang pemasukan kepada Negara dan sumbangan penyelesaian Landerform.

Berdasarkan pendapat di atas, maka pejabat yang berwenang memberikan hak atas tanah adalah Badan Petanahan Nasional.

Pengertian pendaftaran tanah adalah rangkaian kegiatan yang dilakukan oleh Pemerintah secara terus menerus, berkesinambungan dan teratur, meliputi pengumpulan, pengolahan, pembukuan, dan penyajian serta pemeliharaan data fisik dan data yuridis, dalam bentuk peta dan daftar, mengenai bidang-bidang tanah yang sudah ada haknya dan hak milik atas satuan rumah susun serta hak-hak tertentu yang membebaninya yang diatur pada Pasal 1 PP Pendaftaran Tanah. ${ }^{11}$

Pendaftaran tanah di Indonesia diatur dalam UUPA Nomor 5 Tahun 1960 Pasal 19, kemudian dilaksanakan dengan Peraturan Pemerintah Nomor 10 Tahun 1961 yang berlaku selama 27 (dua puluh tujuh) tahun kemudian diganti dengan PP Nomor 24 Tahun 1997 sebagai revisi atas PP No. 10 Tahun 1961 yang berlaku efektif sejak tanggal 8 oktober $1997 .{ }^{12}$

Kegiatan pendaftaran tanah mempunyai tujuan, yaitu untuk menjamin kepastian hukum dan kepastian hak atas tanah. Hal ini dilakukan bagi kepentingan pemegang hak atas tanah, agar dengan mudah membuktikan bahwa dialah yang berhak atas suatu bidang tanah tertentu, melalui pemberian Sertipikat hak atas tanah. Kepastian hukum yang dimaksud dalam kegiatan pendaftaran tanah di atas adalah: ${ }^{13}$

11 A.P. Parlindungan. (2011). Pendaftaran Tanah di Indonesia. Bandung: Mandar Maju, h. 3.

12 ibid.

${ }^{13}$ Aartje Tehupeiory. (2012). Pentingnya Pendaftaran Tanah di Indonesia. Jakarta: Raih Asa Sukses, h. 9. 
1. Kepastian hukum mengenai orang atau badan yang menjadi pemegang hak;

2. Kepastian hukum mengenai lokasi, batas, serta luas suatu bidang tanah;

3. Kepastian hukum mengenai haknya.

Hal ini diatur sebagaimana telah ditetapkan dalam Pasal 19 ayat (1) UUPA tentang Pendaftaran Tanah yang menyatakan bahwa untuk menjamin kepastian hukum oleh Pemerintah diadakan pendaftaran tanah di seluruh wilayah Republik Indonesia menurut ketentuan-ketentuan yang diatur dengan Peraturan Pemerintah. Adapun pendaftaran tanah yang dimaksud dalam Pasal 19 ayat (1) UUPA tersebut meliputi: ${ }^{14}$

1. Pengukuran, perpetaan, dan pembukuan tanah;

2. Pendaftaran hak-hak atas tanah dan peralihan hak-hak tersebut;

3. Pemberian surat-surat tanda bukti hak yang berlaku sebagai alat pembuktian yang kuat.

Dari penegasan pasal tersebut di atas, jelas sekali bahwa tujuan diadakan pendaftaran oleh pemerintah adalah untuk menjamin kepastian hukum. Kepastian hukum yang dijamin itu meliputi kepastian mengenai: $:^{15}$

a. Letak, batas, dan luas tanah;

b. Status tanah, dan orang yang berhak atas tanah; dan

c. Pemberian surat berupa sertipikat.

Secara garis besar tujuan pendaftaran tanah dinyatakan dalam Peraturan Pemerintah No. 24 Tahun 1997 tentang Pendaftaran Tanah (selanjutnya disebut PP Pendaftaran Tanah), Pasal 3 PP Pendaftaran Tanah menjabarkan bahwa:

1. Untuk memberikan kepastian hukum dan perlindungan hukum kepada pemegang hak atas bidang tanah, satuan rumah susun dan hak-hak lain yang terdaftar agar dengan mudah dapat membuktikan dirinya sebagai pemegang hak yang bersangkutan. Untuk itu kepada pemegang haknya diberikan sertipikat sebagai tanda buktinya;

2. Untuk menyediakan informasi kepada pihakpihak yang berkepentingan temasuk pemerintah agar dengan mudah dapat memperoleh data yang diperlukan dalam mengadakan perbuatan hukum

\footnotetext{
14 ibid, h. 5.

15 ibid, h. 11.
}

mengenai bidang-bidang tanah dan satuan-satuan rumah susun yang sudah terdaftar;

3. Untuk terselenggaranya tata tertib administrasi pertanahan.

Suatu pendaftaran hak atas tanah dilakukan di kantor pertanahan yang berada di wilayah kabupaten atau kotamadya. Dalam melaksanakan tugasnya, BPN dibantu oleh Pejabat Pembuat Akta Tanah (PPAT). PPAT akan membantu pendaftaran mulai dari pemeriksaan tanah sampai dengan lahirnya sertifikat tanah tersebut bahkan PPAT dapat membantu pendaftaran untuk mengalihkan tanahnya.

\section{Kedudukan Hukum Pemilik Tanah Pertanian yang Melebihi Batas Maksimum}

Ruang lingkup dari hak atas tanah meliputi Hak Milik, Hak Guna Usaha, Hak Guna Bangunan, Hak Pakai, Hak Sewa untuk Bangunan, dan Hak atas Tanah yang bersifat sementara. Hak atas tanah bersumber dari hak menguasai yang berasal dari negara atas tanah yang dapat diberikan kepada perseorangan baik Warga Negara Indonesia maupun Warga Negara Asing, sekelompok orang secara bersama-sama, dan badan hukum baik badan hukum privat maupun badan hukum publik.

Wewenang yang dimiliki oleh pemegang hak atas tanah terhadap tanahnya dibagi menjadi dua yaitu wewenang umum dan wewenang khusus. Wewenang yang bersifat umum ialah pemegang hak atas tanah mempunyai wewenang untuk menggunakan tanahnya, termasuk juga tubuh bumi, air dan ruang yang ada diatasnya sekadar diperlukan untuk kepentingan yang langsung berhubungan dengan penggunaan tanah. Sedangkan wewenang yang bersifat khusus ialah pemegang hak atas tanah mempunyai wewenang untuk menggunakan tanahnya sesuai dengan macam hak atas tanahnya.

Macam-macam hak atas tanah dibagi menjadi tiga macam yaitu Hak atas tanah yang bersifat tetap, Hak atas tanah yang akan ditetapkan dengan undangundang, dan Hak atas tanah yang bersifat sementara. Hak atas tanah yang bersifat tetap meliputi Hak Milik, Hak Hak Pakai, Hak Guna Usaha, Hak Guna Bangunan, Hak Membuka Tanah, Hak Sewa Untuk Bangunan, dan Hak Memungut Hasil Hutan, sedangkan Hak Atas Tanah yang akan ditetapkan dengan undang-undang masih belum ada, dan Hak Atas Tanah yang bersifat sementara meliputi Hak 
Gadai, Hak Usaha Bagi Hasil, Hak Menumpang, dan Hak Sewa Tanah Pertanian. Ruang lingkup dari hak atas tanah meliputi Hak Milik, Hak Guna Usaha, Hak Guna Bangunan, Hak Pakai, Hak Sewa Untuk Bangunan, dan Hak Atas Tanah yang bersifat sementara. ${ }^{16}$

Hak Milik sebagai suatu hak kebendaan yang diatur dalam Kitab Undang-Undang Hukum Perdata, dipahami sebagai sebagai suatu hak absolut dan merupakan hak induk dan merupakan sumber dari pemilikan, meskipun dalam perkembangannya hanya menjadi hak milik. ${ }^{17}$

Hak Milik adalah hak turun-temurun, terkuat, dan terpenuhi yang dapat dipunyai orang atas tanah. Turun-temurun artinya hak milik atas tanah dapat berlangsung terus selama pemiliknya masih hidup dan bila pemiliknya meninggal dunia, maka hak miliknya dapat dilanjutkan oleh ahli warisnya sepanjang memenuhi syarat sebagai subjek hak milik. Terkuat artinya hak milik atas tanah lebih kuat bila dibandingkan dengan hak atas tanah yang lain, tidak mempunyai batas waktu tertentu, mudah dipertahankan dari gangguan pihak lain, dan tidak mudah hapus. Terpenuhi artinya hak milik atas tanah memberi wewenang kepada pemiliknya paling luas bila dibandingkan dengan hak atas tanah yang lain, dapat menjadi induk bagi hak atas tanah yang lain, dan penggunaan tanahnya lebih luas bila dibandingkan dengan hak atas tanah yang lain. ${ }^{18}$

Hak milik atas tanah dapat terjadi melalui tiga cara sebagaimana yang disebutkan dalam Pasal 22 UUPA, yaitu Hak Milik atas tanah yang terjadi menurut Hukum Adat, Hak Milik atas tanah terjadi karena Penetapan Pemerintah, dan Hak Milik atas tanah terjadi karena ketentuan undang-undang.

Hak Milik atas tanah yang terjadi menurut Hukum Adat adalah Hak Milik atas tanah yang terjadi dengan jalan pembukaan tanah, yang dimaksud dengan pembukaan tanah adalah pembukaan tanah atau pembukaan hutan yang merupakan bagian tanah ulayat suatu masyarakat hukum adat yang dilakukan secara bersama-sama dengan masyarakat Hukum Adat dan dipimpin oleh Ketua Adat. Hak Milik atas tanah yang terjadi menurut Hukum Adat dapat

\footnotetext{
16 Urip Santoso. (2013). Hukum Agraria. Cetakan III Jakarta: Kencana Prenamedia Group, h. 90.

${ }^{17}$ Aslan Noor. op.cit., h. 42.

${ }^{18}$ Urip Santoso. (2013). op.cit., h. 92.
}

didaftarkan pada Kantor Pertanahan Kabupaten/ Kota setempat untuk mendapatkan sertipikat Hak Milik atas tanah. Hak Milik atas tanah yang terjadi menurut Hukum Adat akan diatur dengan Peraturan Pemerintah. Peraturan Pemerintah yang diperintahkan sampai sekarang belum terbentuk. ${ }^{19}$

Hak Milik atas tanah yang terjadi karena Penetapan Pemerintah semula berasal dari tanah negara. Hak Milik atas tanah ini terjadi karena permohonan pemberian Hak Milik oleh pemohon dengan memenuhi prosedur dan persyaratan yang telah ditentukan oleh Badan Pertanahan Nasional Republik Indonesia. Kepala Badan Pertanahan Nasional atau pejabat dari Badan Pertanahan Nasional yang diberi pelimpahan kewenangan menerbitkan Surat Keputusan Pemberian Hak. Surat Keputusan Pemberian Hak ini wajib didaftarkan oleh pemohon kepada Kepala Kantor Pertanahan Kabupaten/ Kota setempat untuk dicatat dalam buku tanah dan diterbitkan sertipikat hak milik sebagai tanda bukti hak. Pendaftaran Surat Keputusan Pemberian Hak menandai lahirnya Hak Milik atas tanah. ${ }^{20}$

Hak Milik atas tanah yang terjadi karena ketetapan undang-undang ini terjadi karena undangundang yang menciptakannya, sebagaimana yang diatur dalam Pasal I, Pasal II, dan Pasal VII ayat (1) Ketentuan-ketentuan Konversi UUPA. Terjadinya Hak Milik atas tanah ini atas dasar ketentuan konversi menurut UUPA. Sejak berlakunya UUPA pada tanggal 24 September 1960, semua hak atas tanah yang ada harus diubah menjadi salah satu hak atas tanah yang diatur dalam UUPA.

Konversi adalah perubahan status hak atas tanah dari hak atas tanah menurut hukum yang lama sebelum berlakunya UUPA menjadi hak atas tanah menurut UUPA. ${ }^{21}$ Konversi hak atas tanah berkaitan dengan jenis-jenis hak atas tanah yang ada sebelum dan sesudah berlakunya UUPA. Dasar hukum konversi hak atas tanah terdapat di bagian kedua UUPA tentang ketentuan konversi, yaitu Pasal I hingga Pasal VII. Secara garis besar, konversi hak atas tanah terbagi menjadi tiga jenis yaitu konversi hak atas tanah yang berasal dari tanah hak barat, konversi hak atas tanah yang berasal dari tanah bekas hak Indonesia, dan konversi hak atas tanah

\footnotetext{
19 ibid., h. 96.

20 ibid., h. 97.

21 ibid., h. 98.
} 
yang berasal dari tanah bekas swapraja. Berbagai jenis hak atas tanah tersebut kemudian di konversi menjadi hak atas tanah yang baru yaitu hak milik, hak guna usaha, hak guna bangunan, dan hak pakai.

Konversi hak atas tanah yang berasal dari tanah hak barat terdiri dari beberapa jenis, yaitu hak eigendom, hak opstal, hak erfpacht, hak gebruik, dan Bruikleen. Keberadaan hak eigendom sebagai konsep hak milik atas tanah yang bersifat liberal individualistik. Dalam Pasal 570 disebut secara tegas bahwa eigendom adalah hak kebendaan, artinya orang yang mempunyai eigendom berkewenangan untuk mempergunakan benda itu dengan bebas dengan sepenuh-penuhnya dan menguasai benda itu dengan seluas-luasnya. Hukum Barat membedakan antara hak kebendaan dengan hak atas orang. Hak Kebendaan adalah hak yang memberikan kekuasaan langsung atas suatu benda dan dapat dipertahankan terhadap orang lain dan setiap orang harus mengindahkan ketentuan tersebut, seperti eigendom, erfpacht, pand, hypotheek, dan credietverband. Hak Eigendom atas tanah merupakan suatu perhubungan hukum antara seorang pemilik dengan suatu benda tanah itu. ${ }^{22}$

Pada masa sebelum periode tahun 1945-1960, pemerintah belum berhasil membentuk UndangUndang Nasional sebagai pengganti Agrarische Wet 1870. Sejak awal kemerdekaan, pemerintah telah mengambil langkah-langkah konkrit untuk mengakhiri berlakunya peraturan-peraturan produk Hindia-Belanda. Dalam rangka menyesuaikan ketentuan-ketentuan hukum tanah nasional yang berlaku setelah kemerdekaan, sebelum menghasilkan Undang-Undang Agraria yang bercorak nasional, pemerintah telah mengeluarkan berbagai Peraturan dalam bidang Hukum Tanah yang bersiat parsial atau yang menyangkut bagian-bagian tertentu saja dari cakupan Hukum Tanah. Di antara peraturan perundang-undangan yang penting dikeluarkan pemerintah ialah Undang-Undang Nomor 13 Tahun 1948 tentang Penghapusan Hak Konversi, kemudian dilengkapi dengan Undang-Undang Nomor 5 Tahun 1950, kedua undang-undang ini menghapus ketentuan Hak Konversi. ${ }^{23}$

Perubahan hak-hak atas tanah yang ada sebelum berlakunya UUPA untuk masuk dalam sistem hak-

\footnotetext{
${ }^{22}$ Aslan Noor. op.cit., h. 231.

23 ibid., h. 240.
}

hak atas tanah yang ada dalam UUPA, sebagaimana yang diatur dalam bagian kedua dari UUPA tentang Ketentuan-Ketentuan Konversi, seperti Hak Eigendom menjadi Hak Milik, Hak Eigendom kepunyaan Pemerintah Negara Asing menjadi Hak Pakai, Hak Opstal menjadi Hak Guna Bangunan, dan Hak Erfpacht menjadi Hak Guna Usaha. ${ }^{24}$

Apabila terjadi sengketa pertanahan di Indonesia, terutama sengketa secara vertikal yaitu antara masyarakat dengan pemerintah maka kebijakan atau peraturan yang dibuat oleh pemerintah merupakan faktor yang terpenting di dalam upaya penyelesaian sengketa tersebut yang seringkali mengatasnamakan masyarakat atau kepentingan umum yang mana justru mengabaikan hak-hak pribadi dari masyarakat itu sendiri. Problema lain adalah kompetensi pengadilan yang bertugas menyelesaikan gugatan pembatalan hak atas tanah tersebut, apakah menjadi kompetensi Pengadilan Negeri, ataukah Pengadilan Tata Usaha Negara (selanjutnya disebut PTUN). ${ }^{25}$

Pendaftaran tanah dilaksanakan melalui dua sistem, yaitu Pendaftaran Tanah secara Sistematik dan Pendaftaran Tanah secara Sporadik. Pendaftaran Tanah secara Sitematik adalah kegiatan pendaftaran tanah untuk pertama kali yang dilakukan secara serentak yang meliputi semua objek pendaftaran tanah yang belum di daftar dalam wilayah atau bagian wilayah suatu desa/kelurahan.

Pendaftaran tanah secara sistematik didasarkan pada suatu rencana kerja dan dilaksanakan di wilayah-wilayah yang ditetapkan oleh Menteri Agraria/Kepala Badan Pertanahan Nasional, dalam melaksanakan pendaftaran tanah secara sistematik, Kepala Kantor Badan Pertanahan Kabupaten/Kota dibantu oleh Panitia Ajudikasi yang dibentuk oleh Menteri Agraria atau Kepala Badan Pertanahan Nasional. Penunjukan panitia ajudikasi untuk membantu tugas Kepala Kantor Pertanahan dalam pendaftaran tanah secara sistematik, dimaksudkan agar tugas-tugas rutin para Kepala Kantor Pertanahan tidak terganggu, mengingat kegiatan pendaftaran tanah secara sistematik pada umumnya bersifat massal dan besar-besaran.

\footnotetext{
${ }^{24}$ ibid., h. 263.

${ }^{25}$ Fani Martiawan Kumara Putra. (2015). Pembatalan Sertifikat Hak Atas Tanah Karena Cacat Administratif Serta Implikasinya Apabila Hak Atas Tanah Sedang Dijaminkan. Jurnal Perspektif. Fakultas Hukum Universitas Wijaya Kusuma Surabaya. Volume 20 No. 2 Edisi Mei, h. 101-117.
} 
Pendaftaran Tanah secara Sporadik adalah kegiatan pendaftaran tanah untuk pertama kali mengenai satu atau beberapa objek pendaftaran tanah dalam wilayah atau bagian wilayah suatu desa/ kelurahan secara individual atau massal. Pendaftaran tanah secara sporadik dilaksanakan atas permintaan pihak yang berkepetingan, yaitu pihak yang berhak atas objek pendaftaran tanah yang bersangkutan atau kuasanya. Selain pendaftaran tanah secara sistematik dan sporadik, dilakukan juga kegiatan pendaftaran tanah yang meliputi kegiatan pengukuran, pemetaan, dan pembukuan hak. ${ }^{26}$

Menurut Peraturan Pemeritah Nomor 24 Tahun 1997 tentang Pendaftaran Tanah dapat diketahui bahwa objek pendaftaran tanah meliputi bidangbidang tanah yang dipunyai dengan Hak Milik, Hak Guna Bangunan, dan Pakai, kemudian Tanah Hak Pengelolaan, Hak Milik atas Satuan Rumah Susun, dan Tanah Negara yang hanya dibukukan dalam daftar tanah dan tidak diterbitkan sertipikat. ${ }^{27}$

Di dalam Undang-Undang Nomor 56 Prp Tahun 1960 tentang Penetapan Luas Tanah Pertanian telah disebutkan mengenai batas-batas luas maksimum tanah pertanian. Penetapan luas maksimum tanah pertanian memakai dasar kekeluargaan, yaitu sesuai dengan ketentuan Pasal 17 UUPA, yang dimaksud dengan kekeluargaan adalah suami, istri, dan anakanaknya yang belum kawin dan yang menjadi tanggungannya yang jumlahnya berkisar tujuh orang, baik laki-laki maupun perempuan dapat menjadi kepala keluarga. Berapa luas tanah yang dikuasai oleh anggota-anggota suatu keluarga, jumlah itulah yang menentukan maksimum luas tanah bagi keluarga yang bersangkutan. ${ }^{28}$

Dalam Pasal 1 ayat (2) Undang-Undang Nomor 56 Prp Tahun 1960 ditetapkan bahwa luas maksimum pemilikan dan penguasaan tanah pertanian yang diperbolehkan adalah di daerah-daerah yang tidak padat, untuk luas maksimum sawah 15 hektar dan untuk tanah kering luas maksimumnya 20 hektar. Sedangkan di daerah-daerah yang padat ini dibagi menjadi tiga kategori yaitu kurang padat, cukup padat, dan sangat padat. Luas maksimum sawah untuk daerah yang kurang padat adalah 10 hektar

\footnotetext{
${ }^{26}$ Aartje Tehupeiory. (2012). Pentingnya Pendaftaran Tanah di Indonesia. Jakarta: Raih Asa Sukses, h. 15.

27 ibid., h. 25.

${ }^{28}$ Urip Santoso II. op.cit., h. 216.
}

dan tanah kering luas maksimumnya 12 hektar. Di daerah yang cukup padat, luas maksimum sawahnya adalah 7,5 hektar, untuk tanah kering maksimum 9 hektar dan untuk di daerah yang sangat padat, luas maksimum untuk sawah ialah 5 hektar sedangkan untuk tanah kering luas maksimumnya 6 hektar. ${ }^{29}$ Luas maksimum tersebut pada ayat (2) pasal ini tidak berlaku terhadap tanah pertanian: 1 . yang dikuasai dengan hak guna-usaha atau hak-hak lainnya yang bersifat sementara dan terbatas yang didapat dari Pemerintah; 2. yang dikuasai oleh badan-badan hukum, antara lain koperasi, yayasan, dan bank-bank milik pemerintah.

Di dalam Pasal 7 UUPA dinyatakan bahwa untuk tidak merugikan kepentingan umum, maka pemilikan dan penguasaan tanah pertanian yang melebihi batas tidak diperkenankan, sehubungan dengan isi dari Pasal 7 tersebut muncul ketentuan mengenai larangan untuk menguasai tanah pertanian yang melebihi batas. Pasal 7 UUPA dikenal dengan sebutan "Pasal anti tuan tanah". Maksud dari adanya ketentuan yang mengatur larangan pemilikan dan penguasaan tanah pertanian yang melebihi batas adalah agar tidak merugikan kepentingan umum, sebab sehubungan dengan terbatasnya persediaan tanah, khususnya di daerah-daerah yang padat penduduknya, pemilikan dan penguasaan tanah yang melebihi batas itu akan menyebabkan kesempatan bagi pihak lain untuk dapat memiliki tanah sendiri menjadi sempit atau hilang sama sekali. Tanah-tanah yang terkena ketentuan larangan pemilikan dan penguasaan tanah pertanian yang melebihi batas maksimum tidak saja tanah-tanah pertanian yang dipunyai dengan Hak Milik, melainkan termasuk tanah-tanah pertanian yang dikuasai dengan hak-hak lain seperti Hak Sewa, Hak Gadai, Hak Usaha Bagi Hasil. ${ }^{30}$

Selebihnya dari tanah-tanah yang terkena ketentuan batas maksimum tanah pertanian ini akan dikuasai oleh pemerintah. Untuk selanjutnya diredistribusikan kepada petani-petani yang

\footnotetext{
${ }^{29}$ Menurut Kamus Besar Bahasa Indonesia, yang dimaksud dengan sawah adalah tanah yang digarap dan diairi untuk tempat menanam padi atau dengan kata lain tanah irigasi, tanah kering adalah tanah yang tidak irigasi, "Kamus Besar Bahasa Indonesia". website: http://kbbi.web.id/sawah, http://kbbi. web.id/tanahkering. Diakses pada tanggal 06 Januari 2016.

${ }^{30}$ ibid., h. 214.
} 
memenuhi persyaratan sebagaimana ditentukan dalam peraturan perundangan. ${ }^{31}$

Larangan pemilikan tanah pertanian yang melebihi batas maksimum ini, maka bagi orang-orang atau keluarga yang mempunyai tanah pertanian yang melebihi batas maksimum diwajibkan melaporkan kepada Kepala Kantor Pertanahan Kabupaten/Kota yang wilayah kerjanya meliputi letak tanah yang bersangkutan. Bagi suatu keluarga kewajiban lapor dibebankan kepada Kepala Keluarganya, meskipun tanah-tanah yang dilaporkan milik anggota-anggota keluarganya masing-masing. Segala perbuatan yang dimaksudkan untuk memindahkan hak atas tanah agar tidak terkena atau terhindar dari ketentuan wajib lapor ini tidak diperkenankan, kecuali ada izin dari Kepala Kantor Pertanahan Kabupaten/ Kota yang wilayah kerjanya meliputi letak tanah yang bersangkutan. Kewajiban lapor itu disertai dengan sanksi yang diatur dalam Pasal 10 UndangUndang Nomor 56 Prp Tahun 1960, berupa hukuman kurungan selama tiga bulan dan atau denda. Selain sanksi pidana, ditentukan pula bahwa jika terjadi tindak pidana yang berupa pelanggaran terhadap Pasal 3 tersebut, maka tanah yang selebihnya dari batas maksimum jatuh kepada negara tanpa ganti kerugian dalam bentuk apapun. Pemilik tanah pertanian diberi kesempatan untuk mengemukakan keinginannya mengenai bagian tanah yang mana yang akan diambil oleh negara. Jatuhnya tanah tersebut kepada negara berlaku karena hukum, artinya tidak memerlukan putusan hakim, yaitu setelah ada keputusan pengadilan yang mempunyai kekuatan untuk dijalankan, yang menyatakan bahwa benar terjadinya tindak pidana yang merupakan pelanggaran terhadap Pasal 3 Undang-Undang Nomor 56 Prp Tahun 1960.32

Dalam rangka pembatasan maksimum kepemilikan tanah pertanian tersebut di atas yang mengakibatkan perombakan mengenai kepemilikan tanah serta hubungan-hubungan hukum yang bersangkutan dengan pengusahaan tanah tersebut disebut dengan Landreform. Di mana Landreform bertujuan agar masyarakat adil dan makmur dapat terselenggara dan khususnya taraf hidup para petani meninggi dan taraf hidup seluruh rakyat jelata meningkat. Serta bertujuan untuk memperkuat

\footnotetext{
${ }^{31}$ Urip Santoso. (2013). loc.cit.

${ }^{32}$ Urip Santoso. op.cit., h. 217.
}

dan memperluas pemilikan tanah untuk seluruh Indonesia, terutama kaum tani, hal ini berdasarkan Dewan Pertimbangan Agung Nomor $1 / \mathrm{Kpts} / \mathrm{Sd} /$ II/69.33

\section{Mekanisme Redistribusi Tanah Pertanian yang Melebihi Batas Maksimum Berdasarkan Aturan Perundang-undangan}

Landreform merupakan perombakan pemilikan tanah serta hubungan-hubungan hukum yang berkaitan dengan pengusahaan tanah. Di dalam Undang-Undang Nomor 56 Prp Tahun 1960 merupakan Undang-Undang Landreform Indonesia yang mengatur tiga persoalan, antara lain penetapan luas tanah maksimum pemilikan tanah pertanian, penetapan luas minimum pemilikan tanah pertanian dan larangan untuk melakukan perbuatan-perbuatan yang mengakibatkan pemecahan pemilikan tanahtanah itu menjadi bagian-bagian yang terlampau kecil, dan soal pengembalian dan penebusan tanah-tanah pertanian yang digadaikan. ${ }^{34}$ Tujuan dari landreform yaitu pertama, untuk mengadakan pembagian yang adil atas sumber penghidupan rakyat tani yang berupa tanah, dengan maksud agar ada pembagian hasil yang adil pula, dengan merombak struktur pertanahan guna merealisasi keadilan sosial. Kedua, untuk melaksanakan prinsip tanah untuk tani, agar tidak terjadi lagi tanah sebagai objek spekulasi dan objek pemerasan. Ketiga, untuk memperkuat dan memperluas hak milik atas tanah bagi setiap Warga Negara Indonesia, baik laki-laki maupun wanita, yang berfungsi sosial. Keempat, untuk mengakhiri sistem tuan-tuan tanah dan menghapuskan pemilikan dan penguasaan tanah secara besar-besaran dengan tak terbatas dengan penyelenggaraan batas maksimum dan batas minimum untuk tiap keluarga. Kelima, untuk mempertinggi produksi nasional dan mendorong terselenggaranya pertanian yang intensif secara gotong-royong dalam bentuk koperasi dan bentuk gotong-royong lainnya, untuk mencapai kesejahteraan yang merata dan adil, bersamaan dengan sistem perkreditan yang khusus ditujukan kepada golongan tani. ${ }^{35}$

${ }^{33}$ Ngakan Putu Muderana. "Landreform dan Revolusi Nasional Indonesia”. Perspektif. Vol. 2 No. 2 Juli 1997, h. 33-44.

${ }^{34}$ ibid., h. 38.

35 Boedi Harsono. (2003). Hukum Agraria Indonesia Sejarah Pembentukan Undang-Undang Pokok Agraria Isi dan Pelaksanaannya. Jakarta: Djambatan, h. 330. 
Tanah-tanah objek landreform yang akan diredistribusikan kepada para petani penggarap menurut ketentuan Pasal 1 Peraturan Pemerintah Nomor 224 Tahun 1961, meliputi: ${ }^{36}$

1. Tanah-tanah selebihnya dari batas maksimum sebagaimana yang dimaksudkan dalam UndangUndang Nomor 56 Prp Tahun 1960.

2. Tanah-tanah yang diambil oleh pemerintah, karena pemiliknya bertempat tinggal di luar daerah kecamatan letak tanahnya atau karena pemilikan tanah absentee menyebabkan: Pengusahaan tanah yang tidak ekonomis; Menimbulkan sistem penghisapan; Ditelantarkan.

3. Tanah-tanah swapraja dan bekas swapraja yang dengan berlakunya ketentuan UUPA menjadi hapus dan beralih kepada negara.

4. Tanah-tanah lain yang langsung dikuasai oleh negara misalnya bekas tanah partikelir, tanahtanah dengan hak guna usaha yang telah berakhir waktunya, dihentikan atau dibatalkan.

5. Tanah-tanah lain, tidak termasuk didalamnya tanah-tanah wakaf dan tanah-tanah untuk peribadatan.

Selanjutnya sesuai Keputusan Kepala Badan Pertanahan Nasional Nomor 25 Tahun 2002 tentang Pedoman Pelaksanaan Permohonan Penegasan Tanah Negara menjadi Tanah Objek Landreform, menyatakan tanah-tanah negara lainnya yang akan ditegaskan menjadi objek landreform oleh Badan Pertanahan Nasional meliputi: 1. Tanah negara bebas; 2. Tanah-tanah bekas Hak Erfpacht; 3. Tanah-tanah bekas Hak Guna Usaha yang telah berakhir waktunya dan tidak diperpanjang oleh pemegang hak atau telah dicabut atau dibatalkan oleh Pemerintah; 4. Tanahtanah Kehutanan yang telah digarap atau dikerjakan oleh rakyat dan telah dilepaskan haknya oleh instansi yang bersangkutan; 5 . Tanah-tanah bekas gogolan; 6 . Tanah-tanah bekas Hak Adat atau Ulayat. ${ }^{37}$

Tanah-tanah objek landreform sebelum dibagibagikan kepada petani penggarap, terlebih dahulu dinyatakan sebagai tanah-tanah yang dikuasai oleh negara. Untuk menentukan pemilihan bagian-bagian tanah mana yang akan diperuntukkan bagi bekas

${ }^{36}$ I Nyoman Budi Jaya. (1989). Tinjauan Yuridis Tentang Redistribusi Tanah Pertanian Dalam Rangka Pelaksanaan Landreform. Yogyakarta: Liberty, h. 22.

${ }^{37}$ Arba. (2015). Hukum Agraria Indonesia. Jakarta: Sinar Grafika, h. 181. pemilik dan bagian mana yang langsung dikuasai oleh Pemerintah, ada beberapa faktor yang harus diperhatikan, yaitu: 1. Letak tanah yang masih memungkinkan penggarapan yang efisien dari tempat tinggal; 2 . Kesatuan tanah yang tetap dimiliki pemiliki sedapat mugkin merupakan satu komplek; 3 . Kesuburan tanah dari tanah yang tetap dimiliki dan diserahkan, diusahakan seimbang. ${ }^{38}$

Terhadap ketentuan larangan pemilikan tanah pertanian yang melampaui batas, ada beberapa tanah yang dikecualikan, yaitu: 1 . Tanah yang dikuasai dengan Hak Guna Usaha; 2. Tanah yang dikuasai dengan hak-hak sementara, terbatas pada yang didapatkan dari pemerintah, misalnya tanah jabatan; 3. Tanah yang dikuasai oleh badan-badan hukum. ${ }^{39}$

Mengenai hal ini, diatur dalam Peraturan Pemerintah Nomor 224 Tahun 1961 khususnya Pasal 8 dan 9. Dalam Pasal 8 ayat (1) Peraturan Pemerintah Nomor 224 Tahun 1961 ditentukan, bahwa petani penggarap yang mungkin menerima tanah-tanah Redistribusi adalah petani-petani yang tergolong dalam prioritas sebagai berikut: 1. Penggarap yang mengerjakan tanah yang bersangkutan; 2. Buruh tani tetap pada bekas pemilik, yang mengerjakan tanah yang bersangkutan; 3. Pekerja tetap pada bekas pemilik tanah yang bersangkutan; 4. Penggarap yang belum sampai 3 tahun mengerjakan tanah yang bersangkutan; 5. Penggarap yang mengerjakan tanah hak pemilik; 6. Penggarap tanah-tanah yang oleh Pemerintah diberi peruntukkan lain berdasarkan Pasal 4 ayat (2) dan (3); 7. Penggarap yang tanah garapannya kurang dari 0,5 hektar; 8 . Pemilik yang luas tanahnya kurang dari 0,5 hektar; 9. Petani atau buruh tani lainnya. ${ }^{40}$

Di antara para petani yang mendapat prioritas tersebut, terdapat beberapa golongan petani yang diberikan pengutamaan di atas petani-petani lain yang ada dalam golongan prioritas yang sama, yaitu: 1. Petani yang mempunyai ikatan keluarga sejauh tidak lebih dari dua derajat dengan bekas pemilik, dengan ketentuan sebanyak-banyaknya 5 orang; 2 . Petani yang terdaftar sebagai veteran; 3 . Petani janda pejuang kemerdekaan yang gugur; 4. Petani yang menjadi korban kekacauan.

\footnotetext{
${ }^{38}$ I Nyoman Budi Jaya. op.cit., h. 23.

39 ibid., h. 29.

${ }^{40}$ I Nyoman Budi Jaya. loc.cit.
} 
Dalam Pasal 9 Peraturan Pemerintah Nomor 224 Tahun 1961 ditentukan, bahwa tidak semua petani yang digolongkan dalam prioritas tersebut Pasal 8 di atas akan mendapat pembagian tanah, karena di samping mengingat tersedianya tanah yang akan dibagikan mereka juga harus memenuhi syarat-syarat tertentu, yaitu:

1. Syarat umum, berlaku bagi semua petani dalam segala golongan prioritas. Jika salah satu syarat umum tidak dipenuhi, meskipun sudah dimasukkan dalam golongan prioritas, ia tidak akan mendapatkan pembagian tanah. Adapun syarat umum bagi petani penggarap yang akan menerima redistribusi tanah pertanian adalah sebagai berikut: a. Warga Negara Indonesia (WNI); b. Bertempat tinggal di Kecamatan tempat letak tanah yang bersangkutan; c. Kuat kerja dalam pertanian.

2. Syarat khusus, berlaku bagi tiap-tiap golongan prioritas. Walaupun syarat umum sudah dipenuhi, akan tetapi jika syarat khusus yang berlaku bagi golongan tidak dipenuhi, maka yang bersangkutan tidak akan mendapatkan pembagian tanah. Adapun syarat khusus bagi petani penggarap yang akan menerima Redistribusi tanah adalah sebagai berikut: a. Bagi para petani yag tergolong dalam prioritas $\mathrm{a}, \mathrm{b}, \mathrm{e}$, $\mathrm{f}$, dan g di mana telah mengerjakan tanah yang bersangkutan sekurang-kurangnya tiga tahun berturut-turut; $b$. Bagi petani yang tergolong dalam prioritas $\mathrm{d}$, di mana telah mengerjakan tanahnya dua musim berturut-turut; c. Bagi para pekerja tetap yang tergolong dalam prioritas $\mathrm{c}$, di mana telah bekerja pada bekas pemilik tanah selama tiga tahun berturut-turut. ${ }^{41}$

Adapun tahapan-tahapan atau kegiatan-kegiatan yang dimaksud adalah sebagai berikut: ${ }^{42}$ Pertama, Kegiatan pendaftaran dan penelitian. Setelah diundangkannya UUPA yang kemudian disusul dengan berlakunya Undang-Undang Nomor 56 Prp tahun 1960 tentang penetapan luas tanah pertanian, maka mulai diadakan pendaftaran pemilik-pemilik tanah yang diduga mempunyai tanah kelebihan dari batas maksimum, kemudian diikuti dengan penelitian yang dilakukan oleh Panitia Landreform Daerah Tingkat II yaitu oleh Bupati/Walikota madya Kepala

\footnotetext{
41 ibid., h. 25.

42 ibid., h. 35.
}

Daerah untuk meneliti kebenaran atas hasil-hasil laporan itu. Laporan-laporan yang masuk di Kantor Agraria Kabupaten, disusun secara teratur untuk seluruh daerah Tingkat II, sehingga dengan mudah dapat diketahui jumlah pelapor serta luas tanah yang dilaporkan untuk masing-masing desa dan kecamatan yang terkena ketentuan peraturan perundangundangan yang mengatur tentang pemilikan/ penguasaan tanah kelebihan maksimum. Atas dasar bahan-bahan tersebut, pelapor akan diperiksa di Kecamatan yang bersangkutan dan kepada Camat diberitahukan tentang penetapan waktu, tempat, dan pelapor-pelapor yang akan diperiksa. Orang-orang yang berkepentingan atau pelapor dipanggil dan dikumpulkan di kecamatan masing-masing untuk diminta keterangan-keterangannya mengenai tanah pertanian yang dimilikinya, dengan membawa: 1 . Keterangan penduduk; 2. Surat-surat bukti tanah, petuk, akta jual-beli, hibah, warisan, wasiat, dan lainlain; 3. Pada waktu pemeriksaan Kepala Desa harus hadir dengan membawa: Register penduduk; Register Letter C; Register jual-beli tanah; Register warisan, hibah tanah; Register gadai/bagi hasil/sewa tanah.

Pemeriksaan dilakukan oleh anggota-anggota Badan Pekerja Panitia Landreform Kabupaten dengan disaksikan oleh Camat dan Kepala-kepala desa yang bersangkutan. Dalam pelaksanaan pemeriksaan/ penelitian, hal-hal yang harus diperhatikan adalah: 1 . Nama dan alamat/tempat tinggal pelapor; 2. Jumlah anggota keluarga pelapor yang menjadi tanggungan sepenuhnya dan jumlah pekerja tetap atau pembantu pada keluarga pelapor; 3. Letak dan luas tanah, nomor petuk, kitir, atas nama siapa terdaftarnya dalam buku Letter C desa itu; 4. Diteliti bidang-bidang tanah yang belum dilaporkan; 5. Bagian-bagian tanah (luas dan letak) yang dilepaskan atau yang akan diserahkan kepada pemerintah; 6 . Tindakan penetapan bagian tanah untuk bekas pemilik.

Untuk menetapkan bagian-bagian tersebut, kepada pelapor diberikan kesempatan untuk mengajukan usul bagian-bagian tanah yang akan tetap dimiliki dan bagian-bagian tanah yang harus diserahkan kepada Pemerintah. Dengan memperhatikan usul-usul tersebut disertai pertimbangan Ketua Panitia Landreform Daerah Tingkat II memberikan keputusan menetapkan bagian-bagian tanah mana untuk bekas pemilik. Keputusan tersebut kemudian dikirimkan kepada 
orang-orang yang bersangkutan. Untuk mengetahui keadaan nyatanya dari letak tanah harus disaksikan oleh Camat/Kepala Desa yang bersangkutan masingmasing selaku Ketua Panitia Landreform Daerah tersebut.

Untuk persiapan atau mempermudah pengukuran, maka penggarap tanah yang bersangkutan dapat ikut menyaksikan pelaksanaan dari keputusan ini. Selanjutnya dilakukan pengukuran terhadap tanah-tanah yang akan diserahkan kepada negara. Pengukuran dilakukan oleh Panitia Landreform daerah Tingkat II. Hasil-hasil pengukuran dibuat dalam bentuk gambar dengan diterangkan batasbatas luasnya, nomor Persil/Letter C desa, bekas pemiliknya, para penggarapnya, jenis dan penggunaan tanahnya, dan sebagainya. Kemudian hasil tersebut dikirim kepada Panitia Landreform Daerah Tingkat II untuk penyelesaian redistribusi dan ganti kerugiannya. ${ }^{43}$

Bahan-bahan keterangan untuk pemberian ganti kerugian. Setelah tanah yang dikuasai oleh pemerintah diukur dan dibuat dalam bentuk gambar, sebagai tindakan selanjutnya adalah menyiapkan bahan-bahan keterangan untuk menetapkan ganti kerugian yang akan diberikan kepada bekas pemilik. Bahan-bahan keterangan ini dibuat oleh Panitia Landrefom Kecamatan atau Panitia Landrefom Desa sebagai bahan bantuan bagi Panitia Landreform Daerah Tingkat II dalam menetapkan pemberian ganti kerugian. Setelah ditetapkan besarnya ganti rugi, kemudian dicantumkan dalam Surat Tanda Penerimaan Penyerahan Hak dan Pemberian Ganti Rugi. Surat tersebut berisi penyerahan hak atas tanah kelebihan kepada pemerintah, serta penetapan besar ganti ruginya. Surat tersebut ditandatangani oleh bekas pemilik sebagai pihak yang menyerahkan tanah, dan oleh Panitia Landreform Daerah Tingkat II sebagai pihak yang atas nama pemerintah menerima penyerahan hak atas tanah. Dengan pemberian surat tersebut kepada bekas pemilik maka tanah-tanah kelebihan dari batas maksimum secara riil atau secara langsung telah dikuasai oleh pemerintah. ${ }^{44}$

\section{Pendaftaran Para Penggarap}

Panitia Landreform Daerah Tingkat II menyelesaikan ganti rugi, Panitia Landreform

\footnotetext{
43 ibid., h. 37.

${ }^{4}$ ibid.
}

Kecamatan dan Panitia Landreform Desa mengadakan pendaftaran para penggarap tanahtanah yang dikuasai oleh pemerintah dalam desa atau kecamatan masing-masing. Dalam daftar tersebut memuat keterangan mengenai: 1. Nama penggarap; 2. Letak tanah yang digarapnya; 3 . Nomor persil; 4. Luas tanah; 5. Jenis tanah; 6. Hasil panen dalam satu tahun. Daftar tersebut dimaksudkan untuk bahan bagi Panitia Landreform Daerah Tingkat II dalam memberikan ijin mengerjakan tanah kepada para penggarap yang bersangkutan dan untuk menetapkan besarnya uang sewa.

Pemberian ijin untuk mengerjakan tanah-tanah kelebihan. Untuk mengadakan redistribusi tanahtanah tersebut kepada petani yang memenuhi syaratsyarat yang telah ditentukan membutuhkan waktu untuk mengadakan penelitian dan pengujian, oleh karena itu tanah-tanah tersebut oleh pemerintah diijinkan untuk dikerjakan kepada penggarap yang bersangkutan dalam jangka waktu paling lama dua tahun.

Di dalam pelaksanaannya yang memberi ijin ialah Panitia Landreform Daerah Tingkat II. Penggarap yang mendapatkan ijin tersebut untuk mengerjakan tanah, diwajibkan membayar uang sewa tiap-tiap tahunnya sebesar $1 / 3$ (satu per tiga) dari hasil panen kotor. Penggarap yang telah mendapatkan ijin belum tentu secara otomatis akan mendapatkan hak milik. Dalam masa dua tahun tersebut, akan diteliti atau diuji terlebih dahulu apakah penggarap telah benarbenar memanfaatkan tanah garapannya sesuai dengan peruntukannya. ${ }^{45}$

\section{Redistribusi}

Redistribusi atau pembagian tanah kepada para petani akan dilakukan setelah masa persewaan untuk tiap-tiap tanah yang bersangkutan diakhiri, yaitu apabila penelitian tentang syarat-syarat pemberian hak milik dan pengujian kepada penggarap telah selesai serta dengan hasil penilaian sesuai dengan yang diharapkan. Penetapan pemberian hak milik dilakukan oleh Panitia Landreform Daerah Tingkat II dengan menggunakan bahan-bahan yang telah dibuat oleh Panitia Landreform Kecamatan/Desa, yaitu tentang daftar orang-orang/petani di tiaptiap kecamatan yang dapat atau ada kemungkinan untuk memperoleh pembagian tanah sebagaimana

45 ibid., h. 38. 
disebutkan dalam Pasal 8 ayat (1) dari Peraturan Pemerintah Nomor 224 Tahun 1961. Setelah pembagian tanah kepada para petani ditetapkan oleh Panitia Landreform Daerah Tingkat II, maka penyelesaian hak milik diserahkan kepada Kepala Direktorat Agraria dengan dilampiri Surat Keputusan Panitia Landreform Daerah Tingkat II yang memuat nama-nama penerima redistribusi. Setelah permohonan usul tersebut diteliti di tingkat Provinsi, maka oleh Kepala Direktorat Agraria diterbitkan Surat Keputusan Hak Milik yang berupa Surat Keputusan Redistribusi kemudian diserahkan kepada penerima redistribusi. ${ }^{46}$

\section{PENUTUP}

\section{Kesimpulan}

UUPA Pasal 7 menjelaskan bahwa pemilikan tanah pertanian yang melebihi batas maksimum tidak diperkenankan, maka kedudukan hukum bagi pemilik tanah pertanian yang melebihi batas maksimum didalam UUPA tidak diperkenankan. Berdasarkan Pasal 3 Undang-Undang Nomor 56 Prp Tahun 1960 yang menjelaskan tentang pemilik dan penguasa tanah pertanian yang melebihi batas maksimum diwajibkan melapor kepada Kepala Badan Pertanahan Kabupaten/Kota dan tanah yang merupakan kelebihan batas maksimum akan di redistribusikan kepada para penerima redistribusi. Pemilik tanah pertanian yang melebihi batas maksimum tetapi tidak melapor, maka pemilik tersebut dapat dikenakan sanksi berupa kurungan selama tiga bulan atau denda sebesar Rp.10.000,-

Berdasarkan ketentuan Pasal 17 ayat (3) UUPA, tanah-tanah pertanian yang melebihi batas maksimum, maka tanah-tanah pertanian tersebut diambil oleh pemerintah dengan diberikan ganti rugi kepada bekas pemiliknya dan tanah-tanah pertanian tersebut di redistribusikan kepada rakyat atau petani yang membutuhkan. Dalam hal redistribusi tanahtanah pertanian yang melebihi batas maksimum dan ganti rugi terhadap bekas pemilik tanah pertanian, ada beberapa faktor dan syarat-syarat yang harus dipenuhi oleh penerima redistribusi dan bekas pemilik tanah pertanian. Tahapan mekanisme redistribusi tanahtanah pertanian yang melebihi batas maksimum diawali dari kegiatan pendaftaran dan penelitian, tindakan penetapan bagian tanah untuk bekas

\footnotetext{
46 ibid., h. 39.
}

pemilik, bahan-bahan keterangan untuk pemberian ganti rugi, pendaftaran para penggarap, pemberian ijin untuk mengerjakan tanah-tanah pertanian yang melebihi batas maksimum, dan yang terakhir adalah redistribusi atau pembagian tanah kepada para petani yang telah memenuhi syarat-syarat yang telah ditentukan oleh peraturan perundang-undangan.

\section{Rekomendasi}

Perlunya kesadaran bagi para pemilik tanah pertanian yang melebihi batas maksimum untuk memahami dan mematuhi peraturan perundangundangan yang telah ada, agar tidak terjadi permasalahan di bidang pertanahan.

\section{DAFTAR BACAAN}

\section{Peraturan Perundang-undangan:}

Undang-Undang Nomor 5 Tahun 1960 tentang

Peraturan Dasar Pokok-Pokok Agraria.

Undang-Undang Nomor 56 Prp Tahun 1960 tentang Penetapan Luas Tanah Pertanian.

Peraturan Pemerintah Nomor 224 Tahun 1961 tentang Pelaksanaan Pembagian Tanah dan Pemberian Ganti Kerugian.

Peraturan Pemerintah Nomor 24 Tahun 1997 tentang Pendaftaran Tanah.

\section{Buku:}

Aartje Tehupeiory. (2012). Pentingnya Pendaftaran Tanah di Indonesia. Jakarta: Raih Asa Sukses.

Achmad Chulaimi. (2007). Hukum Agraria.

Semarang: Fakultas Hukum Universitas Diponegoro.

Adrian Sutedi. (2008).Peralihan Hak Atas Tanah dan Pendaftarannya. Jakarta: Sinar Grafika.

Arba. (2015). Hukum Agraria Indonesia. Jakarta: Sinar Grafika.

Aslan Noor. (2006). Konsep Hak Milik Atas Tanah Bagi Bangsa Indonesia Ditinjau Dari HAM. Cet. I. Jakarta: Mandar Maju.

Boedi Harsono. (2003). Hukum Agraria Indonesia Sejarah Pembentukan Undang-Undang Pokok Agraria Isi dan Pelaksanaannya. Jakarta: Djambatan.

I Nyoman Budi Jaya. (1989). Tinjauan Yuridis Tentang Redistribusi Tanah Pertanian Dalam Rangka Pelaksanaan Landreform. Yogyakarta: Liberty. 
Urip Santoso. (2013). Hukum Agraria. Cetakan III. Jakarta: Kencana Prenamedia Group. . (2014). Pendaftaran dan Peralihan Hak Atas Tanah. Cetakan IV. Jakarta: Kencana Prenadamedia Group.

\section{Jurnal:}

Ngakan Putu Muderana. "Landreform dan Revolusi Nasional Indonesia". Perspektif. Vol. 2 No. 2 Juli 1997, h. 33-44.
Fani Martiawan Kumara Putra. (2015). "Pembatalan Sertifikat Hak Atas Tanah Karena Cacat Administratif Serta Implikasinya Apabila Hak Atas Tanah Sedang Dijaminkan”. Perspektif. Fakultas Hukum Universitas Wijaya Kusuma Surabaya. Volume 20 No. 2 Edisi Mei, h. 101117.

\section{Website:}

Kamus Besar Bahasa Indonesia. http://kbbi.web.id/ sawah, http://kbbi.web.id/tanahkering. diakses pada tanggal 06 Januari 2016. 